\title{
Research on the Construction of an Internet-based Database for Spoken English Testing and Teaching
}

\author{
Tiezhu Jin \\ School of Languages and Communication Studies \\ Beijing Jiaotong University \\ Beijing, China
}

\begin{abstract}
The paper concerned starts with the literature review on spoken English teaching in the College English program, in particular weaknesses in college spoken English teaching, in the light of College English Teaching Requirements. It continues with discussions from scholars over spoken English teaching models and the necessity of constructing an ecosystem for college spoken English teaching and learning. It proceeds to expand on the function, contents, characteristics of the spoken English Database and the barriers to establish such a database, in hope of improving spoken English teaching, facilitating teaching spoken English, producing the desired effect of spoken English teaching, and eventually developing students' abilities to use English in a well-rounded way.
\end{abstract}

Keywords- spoken English; database; language teaching and learning environment

\section{THE NEW PERSPECTIVES OF EXAMINING THE LEARNING PROCESS}

Instead of focusing exclusively on the process of learning, scholars in this field, e.g. in [1], now enlarge their vision while studying the learning process, by incorporating more variables into their work, like the learners' interaction with the whole society, and the status of learning in the whole life of the learners. In addition, scholars become more humane in their researches, caring more for the individuality of the learners and putting more emphasis on the psychological activities of a learner in his or her learning process.

The extended vision of studying the learning process provides much inspiration for foreign language learning and teaching. Firstly, a more open vision should be introduced into the researches on the learning process of the foreign language learners and on foreign language teaching. Secondly, ESL teachers are expected to pay more attention to language learners' individuality, providing them with personalized guidance in teaching. It is also facilitating to the teaching of oral English to the non-English majors in colleges and universities.

\section{THE PROBLEMS CONCERNING OF THE TEACHING OF ORAL ENGLISH}

The purpose of the new college English teaching model is to enhance students' foreign language proficiency, focusing on training students' listening and speaking ability,

This research was supported by a grant from the Scientific Research Fund at Beijing Jiaotong University (2011JBM355), and by a grant from Higher Education Press (A2023021209). and on improving their reading and writing ability as well [2]. As a result, college English teaching is drawing more attention from scholars. At the same time, oral English teaching becomes a top priority in the teaching process for college English teachers. Accordingly, in the actual process of teaching college English, the teaching model has also experienced significant changes, from putting emphasis on reading and writing to focusing on oral skills.

After nearly a decade of teaching reform in the college English program, with all colleges and universities actively promoting the new web-based college English teaching model, either the concept of college English teaching or the actual teaching practice has changed dramatically. In college English teaching, the part of speaking practice is introduced into the teaching of reading and writing, and the classroom design of listening and speaking classes are set to center around the practice of the spoken language skills.

College English teachers and scholars interested in this field College English are actively practice the new teaching model, and strive to optimize the mode of college English teaching, in order to achieve the best teaching effect. It is also true in teaching of oral English for the non-English majors.

With the continuous advance of the teaching reform, college oral English teaching has been greatly improved. However, in college oral English teaching, there is much room for improvement. Firstly, as reference [3] pointed out, college oral English teaching stresses too much on oral output, ignoring the input of the language. Secondly, in the process of teaching, the author also noted that learners have much difficulty in changing from high school learning habit to the mode of learning/teaching in universities; learners are lack of enthusiasm in the practice of oral skills, expecting to learn more language points as what they did in high school. In addition, reference [4] proposed that there is short of a good language environment for college oral English teaching and learning, and students' individuality is paid insufficient attention to in the teaching process.

\section{THE EXPANSION OF THE COLLEGE ORAL ENGLISH TEACHING MODEL}

To approach the problems mentioned above in college oral English teaching, scholars in this field are also actively seeking new theoretical support for improving the teaching 
of oral English, and more importantly put forward many concrete measures to improve the teaching of college English. The researches of these scholars help to formulate the college oral English teaching model, providing a new perspective for the teaching of oral English.

Firstly, reference [5] starting from the speech act theory, proposed that college oral English teaching model should be extended out of the scope of the classrooms; oral English teaching should include the following procedures: diagnostic evaluation, dialogue imitation, scenario assessment, role play, feedback and discussion.

Secondly, reference [6], examining oral English teaching from the perspectives of meme theory, anthropology and psychology, proposed the acquisition and application of nonverbal means of communication should be strengthened in the college English teaching.

In addition, references [4] and [7] explored the oral English teaching from a constructivist point of view, and pointed out that in order to better oral teaching a multilayered teaching model should be introduced. Under such a model, students' individual differences should be respected, the information in classroom communication being increased, a wealth of teaching resources being provided, culture teaching introduced into the teaching practice and a multiple oral evaluation system being constructed and practiced.

\section{THE CONSTRUCTION OF AN ECOLOGICAL} ENVIRONMENT FOR COLLEGE ORAL ENGLISH TEACHING AND LEARNING

In order to better oral English teaching, and to practice the new teaching mode, it is vital to establish a good teaching and learning environment to accommodate the characteristics of the college oral English teaching. Drawing on the researches on oral English teaching conducted by scholars, the author proposes that an ecological environment for oral English teaching and learning in the web-based environment, college oral English teaching should cover curricular teaching, extra-curricular training, interactive training in the social context. Specifically, English teaching and learning environment should include a collaborative learning environment in oral English classrooms and an extra-curricular oral environment [8-9]; at the same time, the entire teaching and learning environment should be guided by the classroom teaching and be operated through the network [9].

\section{THE CONSTRUCTION OF AN INTERNET-BASED DATABASE FOR SPOKEN ENGLISH TESTING AND TEACHING}

The construction of an ecological environment for oral English teaching and learning will be conducive to students' acquisition of good spoken language skills. The research focus of this article, that is, constructing of an internet-based database for spoken English testing and teaching, will be the important support of such a teaching and learning environment. In its full form, such a database is expected to be able to cover all the aspects of the college oral English teaching and learning, such as before-class, in-class, afterclass and assessment.

\section{A. The Functions of an Internet-Based Database for Spoken English Testing and Teaching}

An internet-based database for spoken English testing and teaching is supposed to cover every single procedures of the oral English teaching, and play its part in all aspects of the teaching as follows.

\section{1) Before-class}

An internet-based database for spoken English testing and teaching can be beneficial to the students' input of the language knowledge, and can provide the students with personalized guidance in terms of foreign language learning strategies and effective learning methods. Students, under the guidance of teachers, making use of the database, are expected to get well prepared before class for the upcoming oral activities in classroom teaching, such as previewing new words and useful expressions and phrases, designing activities of oral practice, retrieving and searching themerelated materials and collecting other related learning materials. In other words, the database should be designed to incorporate the language knowledge module, aiming at strengthening input of language knowledge before class [3].

\section{2) In-class}

Students can log into the internet-based database at any time online or offline. In the classroom teaching, teachers and students at any time can log into the database, bettering the design and completion of the teaching activities, and facilitating cooperative learning among students, in the three steps of oral English teaching: context (situation)-to explore (quest)—cooperation (collaboration), just as reported in reference [8].

\section{3) After-class}

The internet-based database for spoken English testing and teaching can make after-class training in oral English more systematic [9]. Such an internet-based database can provide a variety of oral topics in classroom teaching and personalized learning materials to the learners, making them better grasp the language knowledge taught in classroom, and enabling learners to have more learning materials to repeatedly practice and improve on their speaking skills as well.

\section{4) Assessment of the learners' speaking ability}

Similar to the teaching of other courses in college, college English teaching needs the necessary means to assess the learners' speaking ability. A mature and well-designed database for spoken English teaching and learning will include a module of assessment, by which schools can not only administer diagnostic evaluation to the learners during their learning process [5]; the college teachers can also provide students with targeted guidance. In other words, such a database can be used to administer both formative assessment and summative assessment to evaluate the learners' spoken language abilities.

To be specific, the students' speaking abilities can be assessed and evaluated with test papers automatically 
generated by the internet-based database. Of course, the assessment of the students' oral abilities actually involves many other procedures, such as collecting the candidates' speaking corpus, scoring, analyzing the students' scores, and the like.

\section{B. The Content of the Internet-Based Database for Spoken English Testing and Teaching}

Such an internet-based database for spoken English testing and teaching is supposed to offer the teachers and students the following categories of learning materials.

\section{1) Multimedia content in classroom teaching}

The internet-based database for spoken English testing and teaching should contain classroom multimedia resources, such as the teachers' courseware, materials and projects of student' cooperative learning (class presentation documents, and other materials in form of audio and video).

\section{2) Network resources (Including the Resources on} Campus and Those on the Internet)

The internet-based database in question should include learning resources on the campus network, ranging from online courses to online platforms of oral English materials. In addition, the database should include spoken English resources on the Internet for students to improve their speaking abilities, such as texts about spoken English, websites for oral English learning, BBS for practicing oral English, etc.

\section{3) Resources in Form of Text, Audio and Video}

Such an internet-based database for spoken English testing and teaching should encompass a multitude of text, audio and video materials. Compared with text materials, the audio and video materials may provide the learners with a more direct perception of the targeted language, by means of sound and image. Thus, such audio and video materials are more conducive to the learners' acquisition and application of non-verbal means in interpersonal communication [6].

\section{The Characteristics of the Internet-Based Database for Spoken English Testing and Teaching}

In order to support the current college English teaching model, such an internet-based database for spoken English testing and teaching is expected to have these features as follows.

\section{1) Being open}

The relevant internet-based database should not be isolated or closed. It should be an open system, which should cover the curricular and extracurricular resources on campus, and related learning resources off campus.

\section{2) Being a key part of the social context}

The internet-based database concerned should be established as an important part of social environment for language acquisition. The database should follow the principles of selecting real life language materials, allowing students to come into contact with the authentic and natural English corpus, and thus to improve their speaking ability.

\section{3) Wider coverage of different types of learners}

The internet-based database for spoken English testing and teaching under discussion should have its extensibility. As we all know, the college English teaching span usually lasts about one to two years. After students' completing their study in college English, there would be no college English classes for them. Therefore, it is better cover all stages of college English teaching and learning in the students' university life. It is also expected to satisfy the needs of high school students of improving their spoken English. More desirably, the database in question should also be extended to serve the teaching and learning of oral English to the parttime adult students.

\section{Issues to be Addressed in the Construction of Such an Internet-Based Database}

The construction of the database is an important part of the college oral English teaching and learning environment. It is expected to facilitate classroom teaching, after-class oral English practice. However, it is worthwhile mentioning that the construction of the database will inevitably encounter some problems.

\section{1) The integration of hardware and teaching resources}

First of all, there is a hardware problem. For example, in order to build up such internet-based database for spoken English testing and teaching, it is necessary to buy a number of servers to integrate existent software and hardware network resources. The integration of different categories of resources will involve the deployment of hardware, and will involve the coordination of the different teaching departments and teaching departments as well.

2) The teachers' incompetence in computer technology

As teachers of college English, they are known to be weak in operating computers. Therefore, in order to build the database aforementioned, it is a must for college English teachers to improve on their computer skills, such as techniques in editing audio and video teaching materials, web site design, data retrieval online and editing of other teaching materials. This poses a great challenge for them. To make full use of the database, college English teachers are obliged to get equipped with good computer skills.

3) The formulation of standards for the teaching and testing of spoken English

Another challenge of the construction of the database in question is to establish a range of teaching objectives and testing standards, that is, different levels of students should learn to different learning objectives and under different testing standards.

For now, there is no relevant detailed teaching objectives and testing standards for spoken English teaching and learning, although the new College English Curriculum Requirements does provide a rough grading standards (i.e. basic requirements, intermediate requirements, and higher requirements). However, teaching and learning objectives for different levels of student in each semester within the college English program are still vague, such as the number of lexical items students should master to meet the teaching 
objectives, the specific amount of useful colloquial phrases and that of functional sentences and structures.

Therefore, while constructing the database in question, designers and college English teachers should begin studying relevant theories to define concrete teaching standards and testing standards for teaching practice in spoken English. Only after these criteria or standards have been established, can designers of the database start to organize the spoken English corpus, test papers, etc., in a scientific and applicable manner.

\section{4) Lack of theoretical support}

Teaching reform with the college English program is a gradual process, so colleges and universities have been carrying out teaching reform through trial and error. In other words, there is no one ready-made theoretical system available for reference; scholars and college English teachers are working hard to establish a perfect teaching model for college English teaching, in order to meet the college English teaching requirements, being busy in practicing, summarizing applicable experiences, and continuing to improve on college English teaching.

With regard to the construction of the internet-based database for spoken English testing and teaching, many issues are in urgent need of theoretical support and precedent experience. They include such questions as how to cater to students' individualized needs, how to achieve seamless interaction among the students online or offline as well as smooth interaction between teachers and students, how to execute assessment of the students' oral ability, how to optimize the feedback process, and so on.

\section{CONCLUSION}

As stipulated in the College English Teaching Requirements, the teaching of spoken English is supposed to enjoy the top priority within the college English program across China. College teachers in different institutions of higher education are striving for the optimal teaching effect and for success on the part of the ESL learners.

Still there is much to do in this field of oral English teaching, since there are some problems on the waiting list to be solved, as mentioned earlier in this article.

Ideally, college English teachers should tailor their teaching to meet the needs of the language learners. However, they work under one same teaching model, taking care of too many students in one class, and doing that within a limited amount of credit hours.

One sensible way out is to build the internet-based database as discussed in detail in the present article, which can help the teachers to accomplish their classroom teaching more effectively, and can also help students with their study in a personalized way.

The databases in question is expected to help in every single procedure of oral English teaching, e.g. class meetings, online learning, students' cooperative learning in class or online, and finally assessment of the language learners' speaking ability.

In order to set up such a database to support the teaching of oral English to the non-English majors, college English teachers have to overcome many barriers, which are afore mentioned.

The present article aims at providing new inspiration for the teaching of oral English. The construction of such a dynamic database will definitely demand much time and effort. As aforesaid, there is little theoretical support for such a task. Perhaps scholars in this field could draw more useful lesson from other fields of language studies, such as corpus linguistics, computer linguistics and so on.

Of course, speaking skill cannot be taught and acquired without students' improvement on other foreign language skills. The five language skills, i.e. reading, writing, listening, speaking, and translating, are supposed to be developed simultaneously on the part of the language learners. Only in this way can they learn English well and acquire the ability to use English competently in their future study or in the workplace.

\section{REFERENCES}

[1] K. Illeris, How we learn [M]. London and New York: Routledge, 2007.

[2] Department of Higher Education, College English Curriculum Requirements [M]. Shanghai: Shanghai Foreign Language Education Press, 2007.

[3] L. Wang, "Strengthen language input, to promote the college English teaching”, Liaoning Institute of Public Administration, vol. 8, no. 12, pp. 137-138, 2006

[4] F. Wang, L. Zhang, "College oral English teaching the problems and solutions”, Yellow River University of Technology, vol. 10, no. 4, pp. 96-97, 2008.

[5] T. Li, "Speech act theory and the teaching of college English", Heilongjiang Higher Education Research, no. 2, pp. 148-150, 2003.

[6] J. Du, D. Tang, "The importance of non-verbal communication in college oral English teaching”, Xiangtan Normal University (Social Science Edition), vol. 30, no. 1, pp. 119-120, 2008.

[7] Y. Yuan, "College oral English teaching reform guided by constructivism”, Inner Mongolia Agricultural University (Social Science Edition), vol. 9, no. 1, pp. 196-198, 2007.

[8] L. Li, "Network-based college oral English teaching based on the constructivist theory”, Entrepreneur world (theory), no. 8, pp. 231232, 2008.

[9] D. Gao, "New college oral English teaching reform”, China Science and Technology Information, no. 1, pp. 199-202, 2007. 